\title{
19.1\%
}

\section{Portrayal of Life Stages on Swedish Municipal Media: A Life Course Perspective}

\section{Wenqian Xu}

\section{Resumo:}

O retrato midiático de idosos é concebido como uma forma de expressão de realidades e expectativas sociais, e a imagem do envelhecimento tem implicações significativas nas relações inter geracionais. Uma perspectiva de curso da vida é sugerida para observar a velhice como a etapa final de desenvolvimento sucessivo da vida e para investigar o significado social da velhice através da comparação entre fases da vida. Este artigo focará em retratos visuais de cidadãos em uma fase específica da vida (primeira infância, infância, adolescência, maioridade e velhice) na nova mídia municipal sueca. Este artigo visa responder à maneira que a municipalidade constrói o retrato visual de cidadãos em diferentes fases da vida, e quais retratos midiáticos de idosos foram produzidos sob uma perspectiva de curso da vida. Para esse estudo, foram executadas análises documentais de diretrizes municipais de linguagem visual e outros documentos pertinentes, também foi realizada uma elaborada análise visual de seis fotos representativas do Facebook publicadas pela municipalidade em 2018. Este artigo revela que a municipalidade formalizou diversidade e inclusão (inclusive etária) como dois objetivos vitais de comunicação, assim como fez uso de uma técnica de agrupamento por fases da vida para análise de audiência. $O$ resultado da análise visual sugere que o retrato visual de cidadãos se comunica com um conjunto de traços atribuídos às fases da vida representadas. Especificamente, o resultado sugere que certos componentes visuais servem para categorizar idosos como um grupo vulnerável, perpetuando estereótipos etários e discriminação geracional na sociedade.

Palavras-chave: curso da vida; fases da vida; retrato midiático; idosos; análise visual. 


\begin{abstract}
:
Media portrayal of older adults is an expression of social realities and expectations, and the image of ageing has significant implications for intergenerational relations. A life course perspective is suggested for viewing old age as the final stage of successive lifespan development and investigating the social meaning of old age through comparisons of life stages. This article focuses on the visual portrayal of citizens at a particular life stage (infancy, childhood, adolescence, adulthood and old age) in Swedish municipal new media. It aims to examine the ways that the municipality visually portrayed citizens at different life stages, as well as the media portrayal of older people that was produced from a life course perspective. This study is based on document analysis of municipal guidelines for visual language and other pertinent documents, as well as indepth visual analysis of six representative Facebook photos published by the municipality in 2018. This article finds that the municipality has designated diversity and inclusiveness (including age) as two vital communication goals, in addition to applying a life-stage grouping technique to audience analysis. Visual analysis reveals that the visual portrayal of citizens is communicated using a set of traits attributed to the life stages represented. Specifically, these findings suggest that the particular visual components serve to categorize older people as a vulnerable group, while perpetuating age stereotypes and ageist perceptions in society.
\end{abstract}

Keywords: life course; life stage; media portrayal; older people; visual analysis.

\title{
Introduction
}

Mass media have been identified as an important venue for constructing and communicating the social meaning of ageing (Milner, Van Norman, \& Milner, 2012). The image of ageing is an expression of social realities and expectations with the potential to shape public perception of ageing processes. A significant amount of media content has been utilized for analysing the portrayal of older people, especially photographic materials. The visual framing power of photos is tied to documentary attributes, the capacity of emotional activation and a picture superiority effect (Olesen, 2018). Negative media portrayal of older people and the affordances of new media have been shown to have implications for ageism and generational conflicts. For example, Vidovićová and Honelová (2018) examined the YouTube videos of Czech political campaigns and suggest that political values are paired with generational membership that exacerbates ageism and generational conflicts in society. On the contrary, new media has the potential to be an inclusive tool for senior citizens taking part in public debates to challenge ageism (Trentham, Sokoloff, Tsang, \& Neysmith, 2015). The agency new media users have for constructing identities using online visual aids has been thoroughly 
documented (Adami \& Jewitt, 2016), and new media enable users to produce, consume and communicate online visual aids to a large extent. For example, Tiidenberg (2018) suggests that older adults present positive aspects of their lives on their Instagram pages, such as good health, fashion, independence and self-sufficiency. Little research exists examining the visual portrayal of older people in new media.

In the context of population ageing, marketing strategists have become more likely to perform life-stage segmentation to capture the characteristics of sub-groups, rather than utilizing generational or chronological age as segmentation criteria. On the one hand, individuals from each generation could currently be undergoing different life stages in light of the de-standardization of life course. Elzinga and Liefbroer (2007) find that the family-life trajectories of young adults in most Western countries have become increasingly dissimilar. Similarly, growing diversity in the work-family life course was identified across British cohorts (McMunn et al., 2015). A set of empirical studies found variability to increase with advancing age (Nelson \& Dannefer, 1992). On the other hand, Loos and Ekström (2014) assert that life-stage segmentation contributes to the pluralistic composition of older consumers. They also argue against the use of chronological age as a principal criterion for marketing based on the social construction of age. Similarly, Moschis (1996; 2012) focuses on life-stage segmentation and argues that it is theoretically based on the behaviours of older consumers resulting from the ageing processes.

Against this backdrop, visual materials provide point-in-time documentation, and the media portrayal of life stages serves to construct the social meanings of life stages. This article draws upon life stage segmentation and focuses on the visual portrayal of life stages, especially the image of old age. Considering old age as the final lifespan stage, the life course perspective (proposed by Narvanen, 2018) suggests looking at specific life-stage groups in relation to others through comparative studies. The present article takes the visual portrayal of different life stages into account, exploring their interrelations, the ways they define each other and the social meanings of old age.

Images of ageing have often been produced and interpreted within specific contexts. Likewise, Ylänne (2015) suggests that images of older adults in the media are highly context-specific, and that cultural constructs produce media portrayals of older people for very specific purposes. One example is the way that $50+$ marketing aims to create the image of successful ageing with consumerist lifestyles. This study chooses to concentrate on the new media operations of a specific Swedish municipality based on the following two reasons. Firstly, Sweden has been confronted with population ageing and stands on the frontiers of social inclusion, especially in terms of providing long-term 
care services and pensions for older people (Government Offices of Sweden, Ministry of Finance, 2017). Secondly, Sweden is one of the world leaders in developing and utilizing information and communication technologies (ICT) in the public sector (OECD, 2018). Specifically, the Swedish public administration has endeavoured to provide citizens with digital amenities and services. Consequently, 92 percent of Swedish municipalities claimed to have an official Facebook page as of 2010 (Larsson, 2013). Concerning the insufficient analysis of the image of ageing produced in the public sector, it is necessary to emphasize media portrayal of older people generated by the public administration throgh the use of new media.

The objective of this study is to advance the understanding of the social construction of life stages within Swedish public administration. The study focuses on the visual portrayal of citizens at distinct life stages (infancy, childhood, adolescence, adulthood and old age), especially older people. It aims to answer two specific questions:

(1) In what way did the municipality construct the visual portrayal of citizens at different life stages?

(2) How does the visual portrayal of older people differ from other life stages?

In order to address these questions, a document analysis of work instructions using visual language in the public administration was conducted. Furthermore, the method of in-depth visual analysis suggested by Hansen and Machin (2013) was utilised for analysing six representative Facebook photos corresponding to life stages and published by the Swedish municipality.

In the following sections, previous studies examining social constructions of life stages, visual portrayal of life stages in media, and media impacts of the visual portrayal of older people will be summarized. Secondly, the research methods section will elaborate on the selection of corpus and coding procedures. Thirdly, the results of analyses and the anonymized Facebook posts will be presented. Finally, key findings will be summarized in accordance with the research questions and discussed in relation to other pertinent studies.

\section{Previous studies}

\section{Social construction of life stages}

Human life is a progression from conception to death that passes through a series of life stages (or life phases). Armstrong (2007) identified 12 life stages: pre-birth, birth, infancy, early childhood, middle childhood, late childhood, adolescence, early adulthood, midlife, mature adulthood, late adulthood and death and dying. Despite several sub-life stages 
named in recent studies (e.g., young adulthood), the present article adopts a life cycle segmentation consisting of five distinct life stages (infancy, childhood, adolescence, adulthood and old age).

The significance of life stages is social rather than biological in nature, constructed from a social science perspective (for example Matthews, 1979; Bene, 2015). Based on ideas of social constructivism, old age is constructed through a concretization process of various assumptions about social interactions (Vesperi, 1985, p.24). Degnen (2007) found ethnographic evidence of older adults constructing ideas of oldness through their observations of the ageing expressions of their similarly aged peers. Additionally, Erol (2009) argues that young people, rather than solely older adults, are involved in constructing ideas of old age. Furthermore, the social construction of adolescence results from interactions in family and school contexts (Lesko, 2012). By the same token, the targeting of large audiences by mass media is seen as playing a key role in constructing age-related concepts through representations and communications.

People may perform multiple roles and experience the ensuing transitions of roles given that the life-cycle transitions often bring about new roles in a sequence. Holstein and Gubrium (2007) wrote that

One is socialized into a progression of roles and outlooks, each of which packs its own set of constructed meanings ... The life course can be viewed as a series of lifelong alterations of roles and self-definitions that proceed with age.

The meanings assigned to life stages are constructed based on consensus concerning developmental roles throughout a lifespan (Clair, Karp, \& Yoels, 1993). Through the lens of media, portraying the prominent role(s) of characters serves to produce and define the social meaning of life stages. Further analysis of roles and the sequence represented in the media can contribute to advancing our understanding of the construction of age and the (de-)standardized life course. A set of roles are commonly identified and studied in family, work and educational contexts. Examples include Entwisle's (2018) evaluation of the performance of children in different divisions of school and neighbourhood, as well as Fischer and colleagues' (2015) examination of the work-family conflict in middle-aged adults resulting from role imbalance. As aids to understanding, photos portray life stages by visually depicting roles and contexts of represented characters.

\section{Visual portrayal of life stages}

While there is a growing body of work examining media portrayal of older people through analysis of visual content in many different formats (e.g., print, television, movies, etc.), 
examining the presence of older adults and their positive/negative representations has been inconsistent. Loos and Ivan (2018) suggest that the image of old age has become more positively portrayed in visual media, especially in commercials and television programmes. Other research has found that older people were presented in association with negative depictions in advertisements, with older individuals depicted as an incompetent population (Lepianka, 2015), as technologically inept and less-adaptable employees (Kroon, van Selm, ter Hoeven, \& Vliegenthart, 2018), or associated with certain commercial products (Prieler, Kohlbacher, Hagiwara, \& Arima, 2015). Many examples exist of older people being unfavourably portrayed, helping to promote the invisibility of presence and otherness of older people. Ylänne (2015) finds that older people often become objects of ridicule or are presented as extreme caricatures, especially as a way of playing down the otherness of older people in advertisements targeting younger consumers.

Analyses of images produced by older people's organizations have shown multiple types of positive visual portrayals. As for empirical evidence, youthful older characters dominate the websites of three Dutch older people's organisations, whereas the physical decay associated with ageing is completely absent (Loos, 2013). Beyond that, older people are mostly represented as healthy/active in examples from seven European countries (Loos et al., 2017). Furthermore, the existence of visual ageism was highlighted by Loos and Ivan (2018), given that the dominant portrayal of ageing well (or successful ageing) addresses individual agency for dealing with ageing, leading to increasing prospects for individual responsibilities in other societal spheres. It is widely argued that variations in ageing processes and lifestyles in the media portrayal of older people make up the heterogeneity of the ageing population. Yet, specific empirical evidence indicates that health-related discourse in British advertisements fails to provide multi-dimensional portrayals of older people (Ylänne, Williams, \& Wadleigh, 2010).

Life stage-related features are reflected in the media portrayal of citizens with advancing age. Specifically, infancy is characterized as a period of trust-sense development (Zuckerman, Frank, \& Augustyn, 1999), and infants are portrayed alongside caregivers and families in advertisements (Henderson, Kitzinger, \& Green, 2000; Foss \& Southwell, 2006) when it comes to developing social-emotional skills. Additionally, Volk, Lukjanczuk, and Quinsey (2007) shed light using photos of infant and children faces on the effectiveness of cuteness for influencing and eliciting parental care. As a transitional period between childhood and adulthood, adolescence encompasses three pivotal transitions, namely from education to the workforce, from dependency to independence, and from irresponsibility to responsibility (Skelton, 2002). Concerning the image of 
adolescence, media scholars have provided a set of studies related to the topics of violence, gender, race, body image, tobacco use, alcohol use, and sexuality (Jamieson \& Romer, 2008). In this regard, it is worthwhile to capture the features of old age embedded in media representations, and in comparison to other life stages.

\section{Media influences of visual portrayal of older people}

Several theories are commonly applied to account for media influences of the image of ageing for individuals and groups. Appel and Weber (2017) expressed support for the stereotype threat theory and found evidence of mediated stereotypes in content negatively impairing stereotyped group members, while non-members were unaffected. Additionally, cultivation theory serves to explain the long-term media effects, while social cognitive theory sheds light on individual knowledge acquisition in the media landscape and in social interactions. With a focus on media portrayal of older people, Kessler, Rakoczy, and Staudinger (2004) argue that the image of ageing may explicitly and implicitly affect how an audience perceives older people and ageing processes.

The premise of analysing the image of ageing has been set as a potential influence on self-perceptions of older people (for example Lumme-Sandt, 2011). In empirical studies, older people have reported feeling absent from media and portrayed using negative stereotypes when present (Bradley \& Longino, 2001). Furthermore, the image of ageing exerts influences on older adults' physical functioning, mental health, life satisfaction and behavioural outcomes (for a detailed review, see Bai 2014). Considering the ways that media impact older people, on the one hand, older audiences are concerned about being negatively represented due to concerns that this portrayal may reinforce ageist perceptions among young people and lead to unfavourable treatment in their daily lives (Healey \& Ross, 2002; Robinson \& Popovich, 2003). On the other hand, the pressure of needing to compare one's self to media portrayals of active ageing may become overwhelming for some (Robinson \& Callister, 2008). It is also noteworthy that older people have the personalized and dynamic perception of the image of ageing based on individual ageing processes.

Several studies have investigated the influences of the image of ageing on young people using college students as a representative sample. Distorted portrayals of older people may serve to misinform young audiences about ageing processes and even compromise sound intergenerational relations (Sedick \& Roos, 2011). Concerning the impacts of visual ageism, young people with an ageist attitude show less compassion and support for incapacitated older people (Bergman \& Bodner, 2015). Given potentially adverse media influences, Cohen (2002) argues for developing critical thinking and media literacy 
skills as a means of challenging media portrayals of older people. The interpretation of images has become the entry point for investigating cultural constructs of ageing through media representations.

\section{Materials and method}

The present analysis consists of two components: a document analysis of the five latest municipal work guidelines for visual language, and a visual analysis of six Facebook photos as a pilot study. Both the documents and Facebook photos were provided by the municipality of Norrköping.

In the context of public administration, images of citizens were produced by both professional and amateur photographers and published by employed professional communicators whose work routines are based on a set of administrative instructions. A document analysis of five relevant Swedish-language archives was performed to better understand the municipality's views on visual language in relation to age (or life stages).

\begin{tabular}{|c|c|c|c|c|}
\hline No. & File name (in English) & File name (in Swedish) & $\begin{array}{l}\text { Publication } \\
\text { date }\end{array}$ & Publisher \\
\hline $\mathrm{D}-1$ & $\begin{array}{l}\text { Guidelines for Social } \\
\text { Media Use }\end{array}$ & $\begin{array}{l}\text { Riktlinje för användning } \\
\text { av sociala medier }\end{array}$ & $\begin{array}{l}\text { revised on } \\
2013-10- \\
28\end{array}$ & $\begin{array}{l}\text { Norrköping } \\
\text { Municipality }\end{array}$ \\
\hline $\mathrm{D}-2$ & $\begin{array}{l}\text { A Source of Inspiration } \\
\text { for Equal } \\
\text { Communication }\end{array}$ & $\begin{array}{l}\text { En inspirationskälla till } \\
\text { jämlik kommunikation }\end{array}$ & 2014 & $\begin{array}{l}\text { Region } \\
\text { Värmland }\end{array}$ \\
\hline D-3 & $\begin{array}{l}\text { Social Media Handbook } \\
\text { of Norrköping } \\
\text { Municipality }\end{array}$ & $\begin{array}{l}\text { Norrköpings kommuns } \\
\text { sociala mediehandbok }\end{array}$ & $\begin{array}{l}2019-01- \\
18\end{array}$ & $\begin{array}{l}\text { Norrköping } \\
\text { Municipality }\end{array}$ \\
\hline D-4 & $\begin{array}{l}\text { Good economic } \\
\text { management - Report by } \\
\text { the administration } \\
\text { (pp.22-23) }\end{array}$ & $\begin{array}{l}\text { God ekonomisk } \\
\text { hushållning } \\
\text { Förvaltningsberättelse }\end{array}$ & $\begin{array}{l}2019 \\
\text { Spring }\end{array}$ & $\begin{array}{l}\text { Norrköping } \\
\text { Municipality }\end{array}$ \\
\hline $\mathrm{D}-5$ & $\begin{array}{l}\text { Imagery of Norrköping } \\
\text { Municipality }\end{array}$ & $\begin{array}{l}\text { Norrköpings kommuns } \\
\text { bildspråk }\end{array}$ & No date & $\begin{array}{l}\text { Norrköping } \\
\text { Municipality }\end{array}$ \\
\hline
\end{tabular}

Table 1. A list of documents 
Visual analysis was performed on photos obtained from the municipality's Facebook page (@NorrkopingsKommun), including captions. The Facebook page is the municipality's primary new media platform, with rich image resources and a record of actively connecting with citizens online.

The present study was designed to select the Facebook photos that are most representative of certain life stages for the purpose of in-depth visual analysis. Thus, photos involving people published on the municipal Facebook page in 2018 were collected, and the four concepts of presence, activity, physical setting and theme ${ }^{1}$ were employed as the screening criteria of the corpus. As shown in Table 2, the most-shown activity, setting and theme in the image of each life stage were identified, and one Facebook photo from each life-stage category was selected to satisfy the screening criteria.

\begin{tabular}{l|l|l|l|l|l|l}
\hline Facebook photographic content in 2018 (in total: 92 images) \\
\hline $\begin{array}{l}\text { Life stage } \\
\text { Infancy }\end{array}$ & Childhood & Adolescence & Adulthood & Old age & $\begin{array}{l}\text { Not } \\
\text { obvious }\end{array}$ \\
\hline $\begin{array}{l}\text { Presence } \\
\text { (percentage) }\end{array}$ & $2(2 \%)$ & $18(20 \%)$ & $9(10 \%)$ & $38(41 \%)$ & $17(18 \%)$ & $8(9 \%)$ \\
\hline $\begin{array}{l}\text { Most-shown } \\
\text { activity } \\
\text { (percentage) }\end{array}$ & $\begin{array}{l}\text { playing } \\
(100 \%)\end{array}$ & $\begin{array}{l}\text { playing } \\
(22 \%)\end{array}$ & $\begin{array}{l}\text { posing } \\
(33 \%)\end{array}$ & $\begin{array}{l}\text { posing } \\
(58 \%)\end{array}$ & $\begin{array}{l}\text { coffee } \\
\text { break/posing } \\
(18 \%)\end{array}$ & $\begin{array}{l}\text { leisure } \\
\text { activities } \\
(50 \%)\end{array}$ \\
\hline $\begin{array}{l}\text { Most-shown } \\
\text { setting } \\
\text { (percentage) }\end{array}$ & $\begin{array}{l}\text { indoors } \\
(100 \%)\end{array}$ & $\begin{array}{l}\text { outdoors } \\
(68 \%)\end{array}$ & $\begin{array}{l}\text { indoors } \\
(56 \%)\end{array}$ & $\begin{array}{l}\text { indoors } \\
(63 \%)\end{array}$ & $\begin{array}{l}\text { indoors } \\
(59 \%)\end{array}$ & $\begin{array}{l}\text { outdoors } \\
(63 \%)\end{array}$ \\
\hline $\begin{array}{l}\text { Most-shown } \\
\text { theme }\end{array}$ & $\begin{array}{l}\text { support } \\
\text { and care }\end{array}$ & $\begin{array}{l}\text { support } \\
\text { and care }\end{array}$ & $\begin{array}{l}\text { culture and } \\
\text { leisure }\end{array}$ & $\begin{array}{l}\text { culture } \\
\text { and } \\
\text { leisure, } \\
\text { work and } \\
\text { business }\end{array}$ & $\begin{array}{l}\text { support and } \\
\text { care }\end{array}$ & $\begin{array}{l}\text { culture } \\
\text { and } \\
\text { leisure }\end{array}$ \\
\hline
\end{tabular}

Table 2. Description of Facebook photos.

Visual analysis for the study utilised the method of photo analysis suggested by Hansen and Machin (2013). Drawing upon the semiotics of Barthes, these authors suggested

\footnotetext{
1 The four concepts of screening criteria were extensively used for content analysing the portrayal of older adults in advertisements (for a detailed review, see Zhang et al. 2006) and correspond to the formulas of visual content (person, action, place and situation) suggested by the municipality.
} 
two levels of analysis (denotation and connotation) for investigating photographic content. Analysts are encouraged to denote the ways that viewers perceive photos and ask systematic questions rather than simply providing an interpretation. Furthermore, the authors introduced several key carriers of connotation (including pose, gaze, objects, setting, viewer positioning and participant $)^{2}$ to examine meanings connected to the symbols. While the photos of older people might be defined as positive media portrayals, it is necessary to describe who is represented, what participants are doing and where they are doing it in a precise manner. Specifically, the present study first employed an in-depth visual analysis of Facebook posts using a six-category analytical scheme (as shown in Table 3). The coding process of denotation indicates an acceptable consistency of interpretations among different viewers, since the tools used here provide a greater level of descriptive power. Secondly, the photos were analysed at the level of connotation from a critical perspective.

\begin{tabular}{l|l}
\hline Concept & Description \\
\hline Pose & body gesture, shape and form \\
\hline Gaze & $\begin{array}{l}\text { looking at us } \\
\text { not looking at us (looking off frame, looking up, looking down) }\end{array}$ \\
\hline Objects & Items \\
\hline Setting & $\begin{array}{l}\text { outdoors (e.g., nature) } \\
\text { interior setting }\end{array}$ \\
\hline Viewer & no identifiable setting \\
positioning & $\begin{array}{l}\text { angles (vertical angle, horizontal angle, oblique angle) } \\
\text { proximity (close shot, longer shot) }\end{array}$ \\
\hline Participant & individual and group \\
\hline Table 3. Analytical scheme (constructed based on Hansen and Machin, 2013)
\end{tabular}

For the presentation of Facebook posts interpreted in this study, identifiable human figures in the pictures were anonymized out of data protection concerns. These posts

\footnotetext{
2 Performing visual analysis needs to consider the carriers of connotations and the context in an integrative manner, as many carriers often serve to connote a concept or a notion through their syntrophic interactions. Thus, it is not suitable to use these carriers as the criteria for screening out the representative photos; instead, this article used four concepts (presence, activity, physical setting, theme) to capture the basics of information transmission.
} 
are accessible by the public. The following section features screenshots of Facebook posts acquired from the PC-device version of the municipal Facebook page.

\section{Results}

\section{Inclusiveness and diversity in the visual communication of municipality}

Norrköping municipality has set forth its general instructions for using visual language with the seven catchwords of Together, Warm, Curious, Exciting, Strong-willed, Diversity and Creativity. Additionally, it suggests four formulas for visual content: person, situation, action and place/symbol (in D-5). These catchwords and formulas, as codes for using pictures and value-expressive appeals, may contribute to constructing positive images of citizens. Presumably, the pictures that comprise the municipality's visual communications are intended to present the active engagement and authenticity of characters, as well as the breadth of administrative works.

Diversity and inclusiveness are set as key goals by Norrköping municipality (in D-4). The municipality has performed and evaluated its visual communications in light of these goals. Specifically, it highlights the presence of certain segments of the population in an inclusive manner. The municipality's 2019 annual report presents a four-category scheme for evaluating performance achieved in 2018: (non-)Nordic background, people with/without disabilities, gender and life stage. The report found that gender equality and social inclusion of people with disabilities were emphasized, whereas age groups were somewhat overlooked in the evaluation.

With a focus on the presence of age categories, evaluation results (in D-4) revealed that the municipality published 1,271 images in 2018 via its media channels (Intranet, norrkoping.se, Norrköping play and printed media). Furthermore, approximately 3,000 recognisable individuals appear in these images (36\% children and young people, $51 \%$ middle-aged people and $13 \%$ older adults). To compare this with actual demographic statistics from the same year, the Norrköping region was composed of $30 \%$ children and young people, $51 \%$ middle-aged people and $19 \%$ older people. Thus, this shows older people to be underrepresented, while children and young people were overrepresented in municipal visual communications.

Mergel (2013) argues that, "the representation objective is clearly to be as inclusive as possible and reach audiences in their social spaces they frequent on a daily basis." Likewise, Norrköping municipality has displayed a marketing orientation that makes use of social media tools. For example, certain age categories are assigned as the major 
audiences, which varies by media platform (in D-3). Concerning variations across social media platforms, it has been revealed that:

- Facebook in Sweden was predominantly used by people aged between 16 and 35 years. The municipal Facebook page was designed to be the primary information venue for all citizens and is followed by netizens aged 18 and older.

- The largest user group of Instagram in Sweden is young people under 35 years old, leading the municipality to make use of Instagram as a platform for reaching younger audiences.

- The largest proportion of Twitter users in Sweden is reported to be aged between 16 and 25 years. The municipality adopts Twitter to connect with professional communicators, politicians and opinion leaders, irrespective of age.

Although the municipality has adopted the approach of social media taking age into account, certain life-stage categories (youth and older people) have not been equivalently and strategically treated as audiences.

\section{Visual portrayal of citizens at distinct life stages}

This study includes a two-level analysis of Facebook photos. This begins with RQ1 to investigate the ways that the municipality constructed visual portrayal of citizens at different life stages based on the aspects of pose, gaze, objects, setting, viewer positioning and participant. The findings of the in-depth visual analysis, corresponding to infancy, childhood, adolescence, adulthood, old age and unknown are presented.

Figure 1 depicts: (1) Pose: two infants are wearing light clothes and playing with painting supplies on the ground, overseen by a male caregiver. The openness of body language connotes joy and energy. (2) Gaze: the figures do not look at viewers. The picture does not demand viewer engagement and can be interpreted as an offering image. (3) Objects: two paintbrushes, two bonsai trees, a stand and a canvas. (4) Setting: interior 
space. (5) Viewer positioning: horizontal angle. (6) Participants: two infants and one adult.

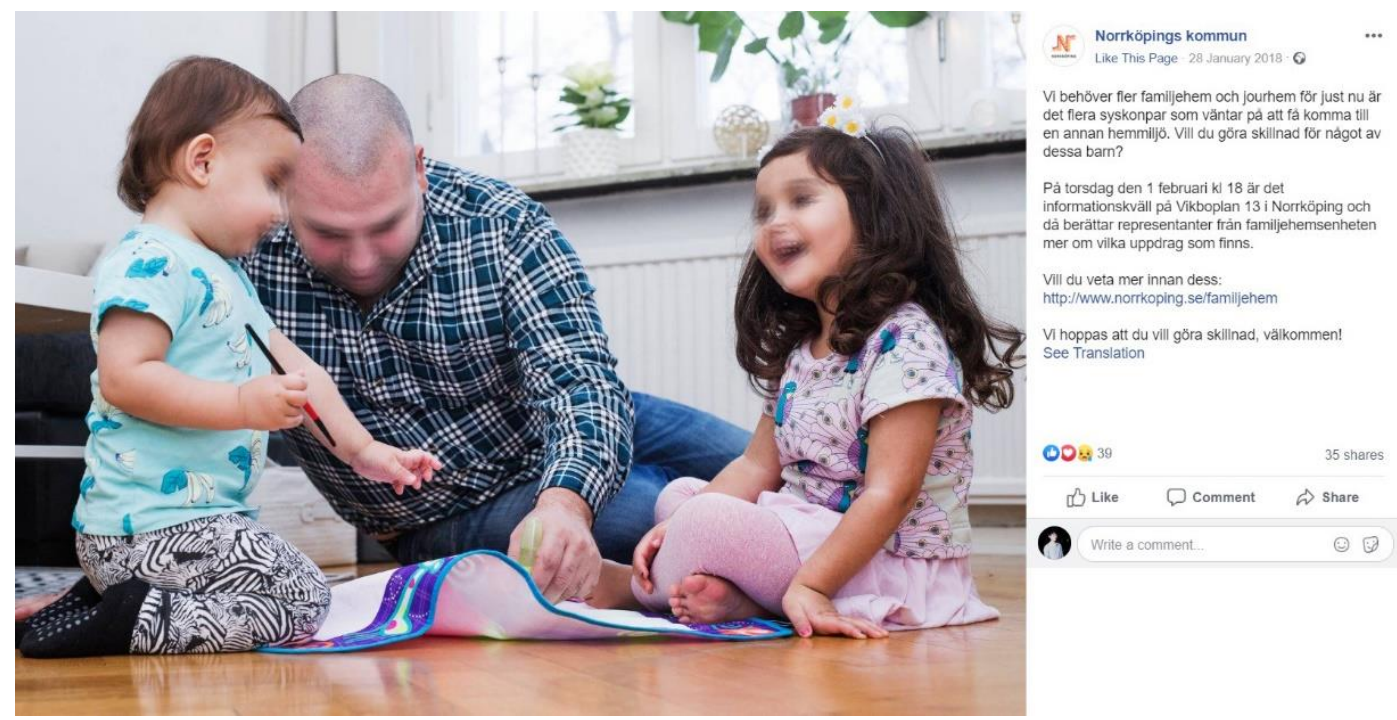

Figure 1. Facebook post of infants

Figure 2 depicts: (1) Pose: three kids are playing on a recreational net climber, with the child pictured at centre stretching out. This indicates that they are controlling themselves consciously and signifies their subjection to the climbing frame. (2) Gaze: the figures do not look at viewers. The picture does not demand viewer engagement, and it can be interpreted as an offering image. (3) Objects: heavy jackets, colourful beanies and gloves produce a visual form of ample protection against the cold weather. (4) Setting: the natural setting carries connotations of freedom and leisure. (5) Viewer positioning: horizontal angle. (6) Participants: children in the picture are portrayed as a group with similar actions and styles of dress, suggesting both cultural and biological visual categorizations.
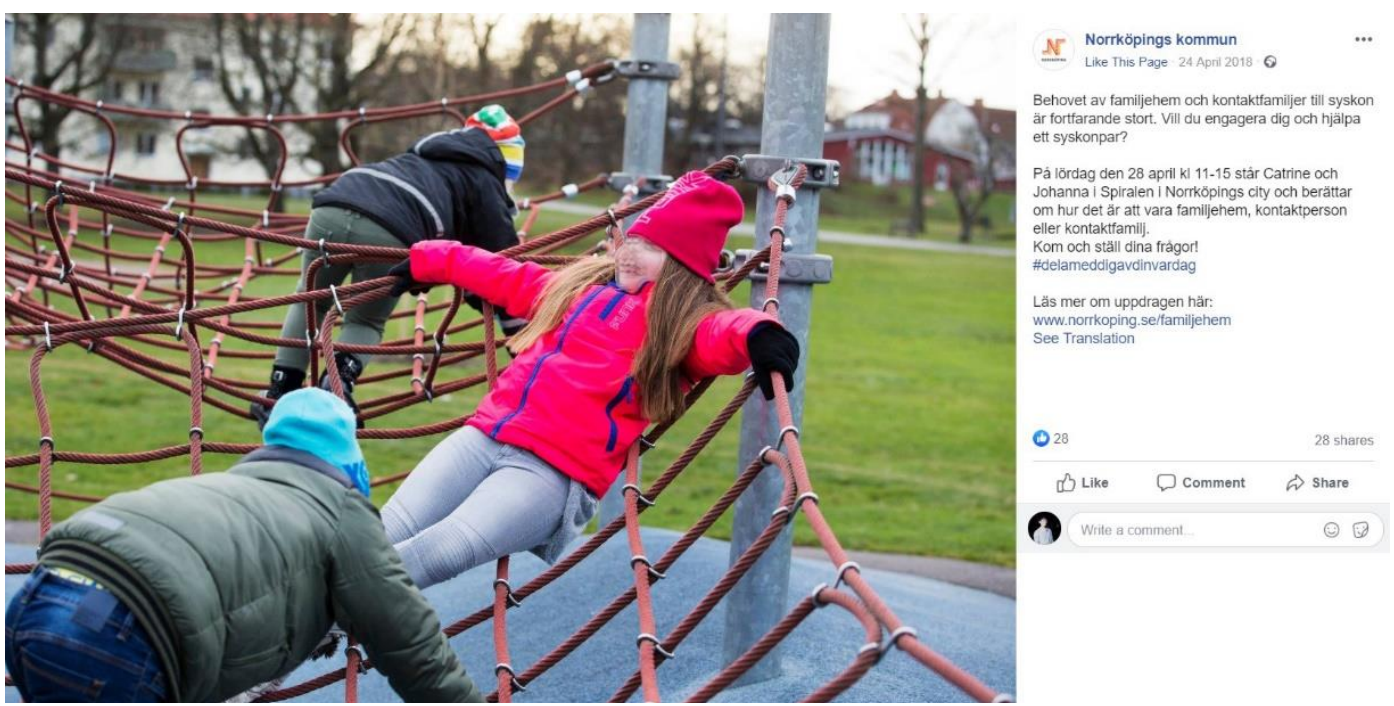

Figure 2. Facebook post of children 
Figure 3 depicts: (1) Pose: poses are diverse and include sitting, standing, leaning and stretching. The looseness of body language in this picture connotes confidence. (2) Gaze: most figures are looking at viewers, offering a sense of an imaginary relationship. Viewers are acknowledged and viewer responses are expected. (3) Objects: SDGs props featured in the picture explicitly refer to the thematic issues and global vision. (4) Setting: interior stairs offer a metaphor for the route (achieve SDGs). (5) Viewer positioning: horizontal angle. Viewers are looked at by figures in a manner that suggest the expectation of viewer involvement. (6) Participants: the placement of SDGs props leads to a cultural visual categorization.

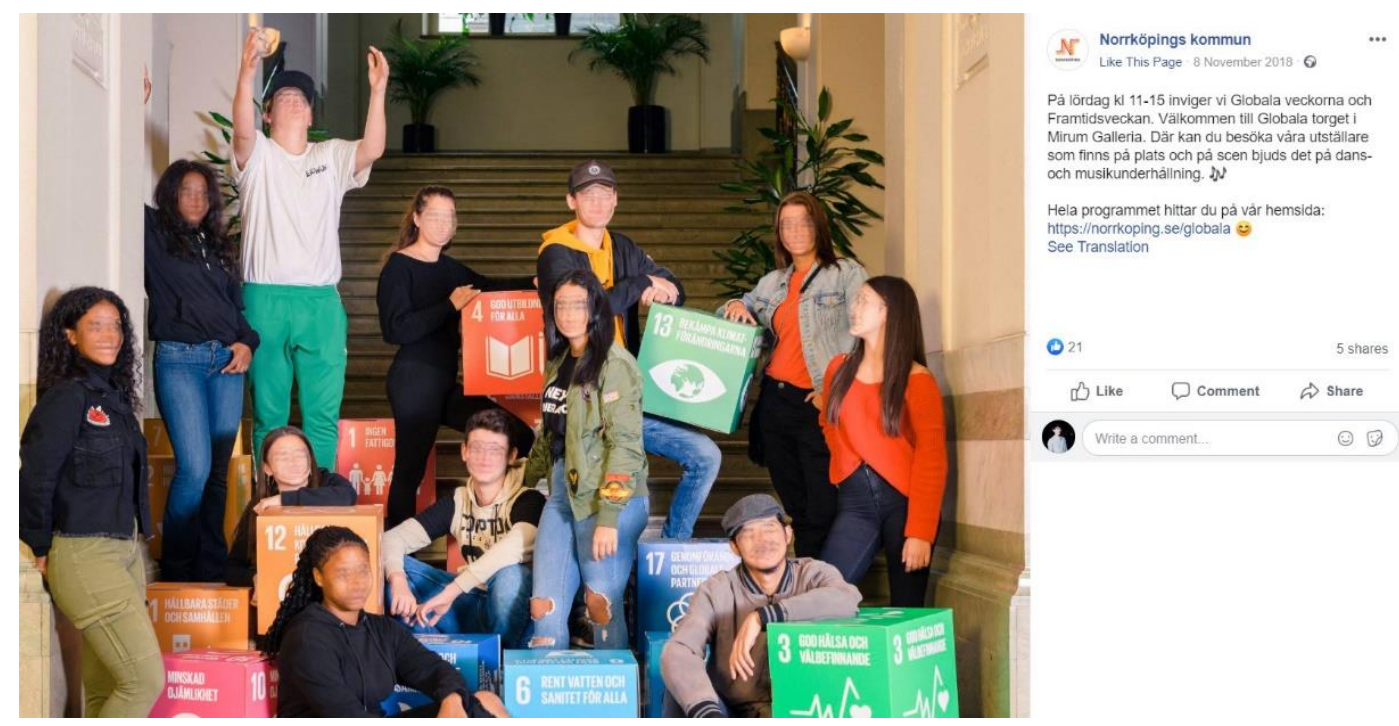

Figure 3. Facebook post of adolescents

Figure 4 depicts: (1) Pose: three figures are standing straight and rigid, indicating their involvement in work routines at an exhibition stand. (2) Gaze: all figures are looking at viewers, which creates an imaginary relationship, acknowledges the existence of viewers and demands their involvement. (3) Objects: two roll-ups, two bistro tables, candies and brochures. These items connote mobility and independence. Besides, the business suit worn by the figure at centre indicates professionalism. (4) Setting: interior space. (5) Viewer positioning: the horizontal angle suggests that viewers and participants are on an equal level. (6) Participants: three people striking the same pose are presented as a homogenized group. 


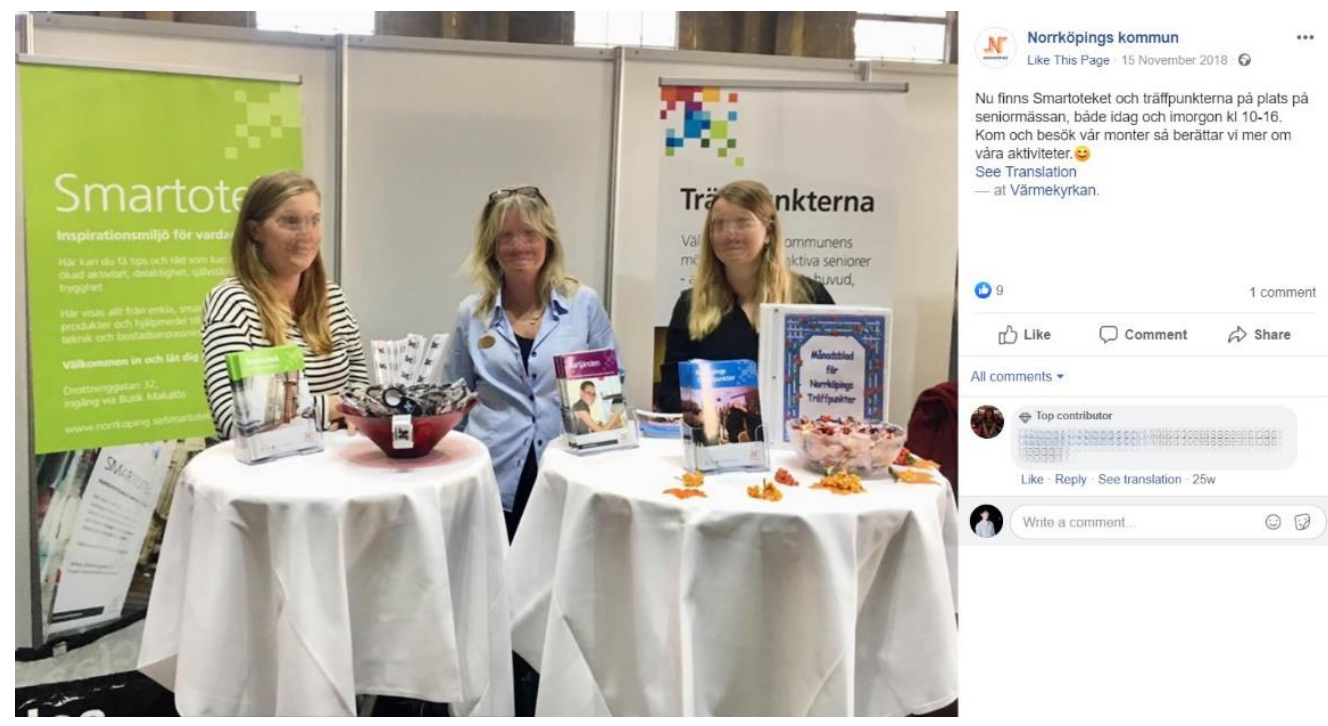

Figure 4. Facebook post of adults

Figure 5 depicts: (1) Pose: one figure pictured in back is leaning back in a chair, representing relaxation. (2) Gaze: two figures are looking down at the table while the other figure is looking at the viewer. The downward gaze is more likely to negatively depict low energy and status. (3) Objects: coffee and bread, bookshelf, table, lamp, window and bonsai tree. The bookshelf and table in particular connote less mobility and less independence. (4) Setting: interior space. The windows and shiny surfaces communicate a clarity of vision and modernity. (5) Viewer positioning: vertical angle. Viewers are looking down at the older figures, making them appear vulnerable. (6) Participants: three older people are portrayed as a homogenized group performing the same action (sign: coffee break). Additionally, this picture categorizes older people biologically (sign: white hair and the absence of young people) and culturally (sign: necklace, Swedish coffee break).

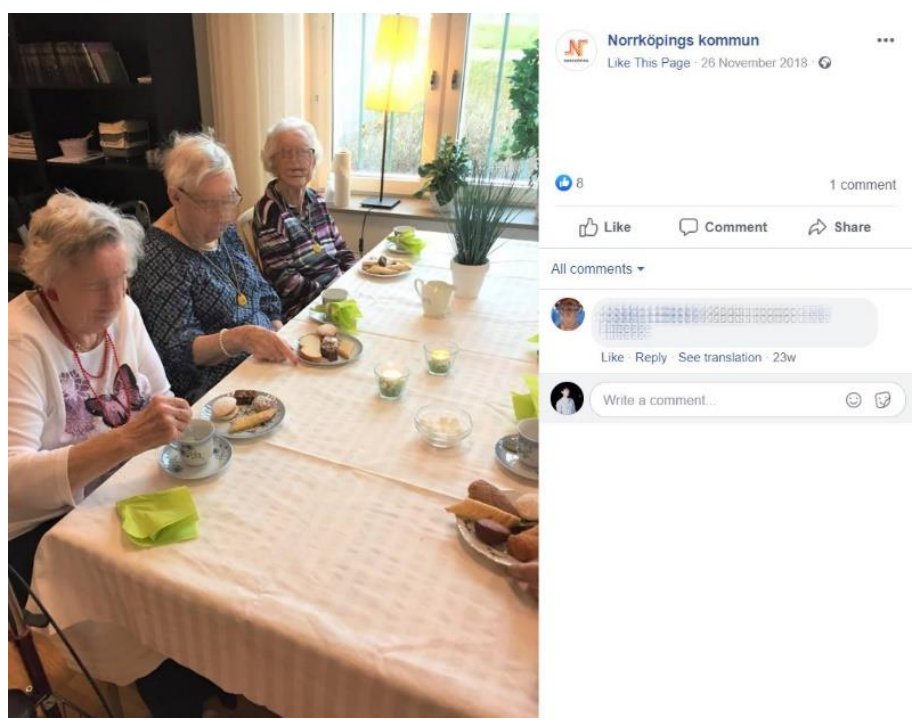

Figure 5. Facebook post of older people 
Figure 6 presents the legs and feet of a skier, ski poles, ski shoes and snow; no identifiable individuals or life stages are shown. This type of pictures is identified as a decontextualized portrayal and fails to construct and challenge the stereotypical portrayal of life stages. In this way, it serves to symbolize a notion or a concept that is commonly shared by the public.

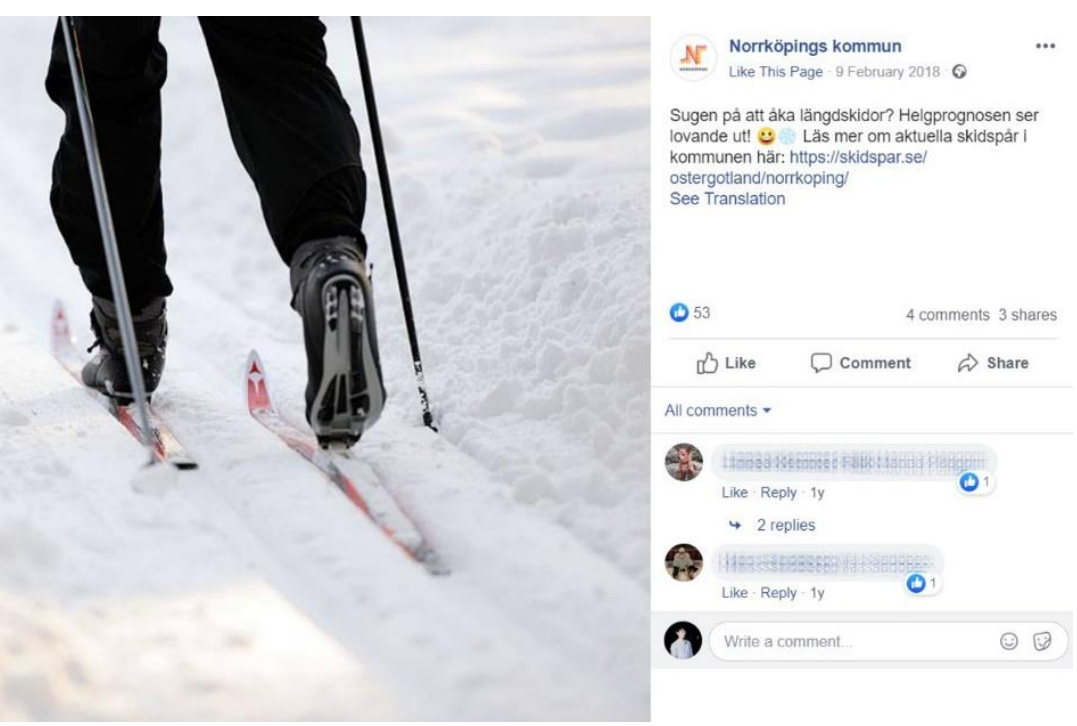

Figure 6. Facebook post of a person at unknown life stage

In addressing RQ2, this study summarized the connotations of photos portraying life stages based on the preceding visual analysis (see Table 4) and examined the visual portrayal of older people in comparison with other life stages. It suggested that older people are underrepresented (18\%) compared to the presence of young and middleaged people on the municipal Facebook page. Nevertheless, this is consistent with their demographic percentage (19\%) in Norrköping. Although the six photos in the present study communicate by portraying positive lifestyles and lively scenes, the analysis of photos puts forward the possibility of distributing the connotations to older people, which were assigned to other life-stage categories.

Specifically, it was revealed that: (1) Pose: body language (looseness/rigidity/openness) presents physical characteristics of figures and connotes their emotional status. Older adults were portrayed in a relaxed status and tended to be associated with joy, confidence and discipline. (2) Gaze: older people can be captured when they look at the viewer, look off frame, and look up (similar to other life stages), rather than look down. (3) Objects: older adults were depicted with wider and blockier objects (signs: bookshelf and table) that often communicate a sense of stability and dependence. They could be depicted with lighter and slimmer objects, as with the SDGs props and roll-ups that appear in the pictures of young people. (4) Setting: most older adults appeared in interior settings, while most children appeared outdoors. Yet, both indoor (sign: nursing home) 
and outdoor (sign: nature) settings can potentially hold positive connotations. (5) Viewer positioning: older adults were portrayed as being vulnerable in power relations (sign: vertical angle). As for the pictures of young people, a sense of involvement/detachment was communicated (sign: horizontal angle). (6) Participants: The majority of pictures present citizens as homogenized groups (signs: uniformity of poses, coffee break) and categorize them into life-stage groups biologically (sign: white hair) and culturally (signs: standard dressing, body adornments).

\begin{tabular}{|c|c|c|c|c|c|}
\hline & Figure 1 & Figure 2 & Figure 3 & Figure 4 & Figure 5 \\
\hline Life stage & Infancy & Childhood & adolescence & adulthood & old age \\
\hline Pose & $\begin{array}{l}\text { joy and } \\
\text { energy }\end{array}$ & $\begin{array}{l}\text { subjection to } \\
\text { physical frame }\end{array}$ & confidence & $\begin{array}{l}\text { subjection to } \\
\text { work routine }\end{array}$ & relaxation \\
\hline Gaze & $\begin{array}{l}\text { offering } \\
\text { image }\end{array}$ & offering image & $\begin{array}{l}\text { demanding } \\
\text { image }\end{array}$ & $\begin{array}{l}\text { demanding } \\
\text { image }\end{array}$ & $\begin{array}{l}\text { offering image } \\
\text { (low status) }\end{array}$ \\
\hline Objects & I & Protection & global vision & $\begin{array}{l}\text { mobility and } \\
\text { independence }\end{array}$ & $\begin{array}{lr}\text { less } & \text { mobility } \\
\text { and } & \text { less } \\
\text { independence }\end{array}$ \\
\hline Setting & I & Freedom & I & I & $\begin{array}{ll}\text { clarity and } \\
\text { modernity }\end{array}$ \\
\hline $\begin{array}{l}\text { Viewer } \\
\text { positioning }\end{array}$ & I & I & involvement & I & vulnerability \\
\hline Participants & I & $\begin{array}{l}\text { visual } \\
\text { categorization } \\
\text { (cultural and } \\
\text { biological) }\end{array}$ & $\begin{array}{l}\text { visual } \\
\text { categorization } \\
\text { (cultural) }\end{array}$ & $\begin{array}{l}\text { homogenized } \\
\text { group }\end{array}$ & $\begin{array}{l}\text { homogenized } \\
\text { group, visual } \\
\text { categorization } \\
\text { (biological) }\end{array}$ \\
\hline
\end{tabular}

Table 4. Life-stage connotations resulting from visual analysis

\section{Discussion and conclusions}

The municipality believes that perception of age is one of the important areas to focus on for achieving diversity and inclusiveness in the domain of media and communications. Age-related concepts have been considered in evaluating the presence of life-stage categories, designing audience-aligned media strategies, and portraying life stages within photographic images. Based on the results of visual analysis, the two research questions proposed above can be answered.

(1) In what way did the municipality construct the visual portrayal of citizens at different life stages? 
Concerning the construction of visual portrayal, photographers have arranged or organized visual components (pose, gaze, objects, setting, viewer positioning and participants) to depict human figures at different life stages. The photographic images publicized on the municipal Facebook page have assigned a set of denotations to citizens at different life stages. Based on these denotations, viewers are able to interpret the image of life stages in an integrated manner. For instance, Figure 3 shows 12 youth using SDGs props and posing for a camera positioned on the stairs. Furthermore, this could be interpreted to be depicting adolescents categorized as a cultural group confidently supporting a global vision of sustainable development and asking for viewer involvement in achieving these goals.

(2) How does the visual portrayal of older people differ from other life stages?

Old age is the final stage of life and represents the accumulated outcomes of the ageing processes. In the context of portraying life course, older people were portrayed as a homogenized group with less mobility and less independence, whereas young people were categorized as a joyful and intimate group enjoying greater freedom and mobility. Despite this study presenting a limited number of photos, alternatives have been provided for portraying older adults as being the same as other life-stage categories. For instance, older people could be captured in rigid or open-body poses, in natural settings, with lighter objects, with a variety of gazes, and with the use of diverse shooting angles. Furthermore, older people could be depicted in de-contextualized images (e.g., bodyimage), as these portrayals often serve to construct a simple notion.

Taking a broader look at the photos of older people published on the municipal Facebook page, older people were mostly depicted as being less physically fit, with lower-mobility items (e.g., wheelchairs, sofa, bench, bathtub, etc.), and using horizontal angles. Additionally, they were portrayed as a homogenized group striking the same poses and taking part in the same activities (e.g., chorus, coffee break). Hence, we can make a general point that older characters should be fully developed and portrayed in a favourable manner.

The approach of social semiotics has been developed as part of the communication sciences (for more detail, see Jewitt \& Oyama, 2001), although it has not been used for analysing the image of ageing. The in-depth visual analysis conducted in this study addresses the importance of descriptive-level analysis based on the aspects of pose, gaze, objects, setting, viewer positioning and participants. Beyond that, it shed lights on the connotations of visual components within the photographic images. Taken the visual component of objects as an example, previous studies suggest that older people commonly appear in advertisements for daily necessities (Prieler et al., 2015), finance- 
related products (Lee, Kim, \& Han, 2006), and health and hygiene products (Lee, Carpenter, \& Meyers, 2007). Recent visual analysis has highlighted the ways that household hygiene products may signify the reconciliation of ecological principals (LeesMaffei \& Maffei, 2019). Drawing upon the semantic content analysis of photos, further indepth visual analysis is needed to explore the connotations of visual components.

Key findings based on visual analysis resulted from adopting a life course perspective to analyse the image of old age, in comparison with other life phases. Using a life course perspective provided an opportunity to identify what visual components were absent or underrepresented in the media portrayal of older people as compared to the portrayal of younger generations. As claimed by Narvanen (2018), the social construction of life stages leads to normalized age practices, and the social meaning of age should be investigated from a life course perspective. Therefore, the analysis presented here can serve as a follow-up to the "design for diversity" approach of combating visual ageism (suggested by Loos \& Ivan, 2018), hopefully giving rise to learning from other life-stage categories and embracing a more pluralistic portrayal of older people.

Still, the visual analysis method was limited due to the small number of photos, meaning that there are lingering concerns about the representativeness of sampled photos. Future studies are needed to examine broader visual materials from a life course perspective, involving more visual components.

\section{Acknowledgements}

I would like to thank Annika Taghizadeh Larsson, Ariana Poli, Atiqur Rahman, Elias Larsson and Gülin Öylü for their comments on the previous version of this paper. I would also like to thank Carlos Alexandre for the Portuguese translation of the abstract. I am also grateful to two anonymous reviewers for their valuable suggestions.

\section{Funding}

This research has received funding from the European Union's Horizon 2020 research and innovation programme under the Marie Skłodowska-Curie grant agreement No 764632.

\section{References}

Adami, E., \& Jewitt, C. (2016). Special Issue: Social media and the visual. Visual Communication, 13(3), 263-270. 
Appel, M., \& Weber, S. (2017). Do mass mediated stereotypes harm members of negatively stereotyped groups? A meta-analytical review on media-generated stereotype threat and stereotype lift. Communication Research DOI: 10.1177/0093650217715543.

Armstrong, T. (2007). The Human Odyssey: Navigating the Twelve Stages of Life. New York City: Sterling Publishing Company.

Bai, X. (2014). Images of ageing in society: A literature review. Journal of Population Ageing, 7(3), 231-253.

Bene, M. (2015). The political construction of old age as reflected in online discussions. Corvinus Journal of Sociology and Social Policy, 6(1), 25-45.

Bergman, Y. S., \& Bodner, E. (2015). Ageist attitudes block young adults' ability for compassion toward incapacitated older adults. International Psychogeriatrics, 27(9), 1541-1550.

Bradley, D., \& Longino, C. (2001). How older people think about images of aging in advertising and the media. Generations, 25(3), 17-21.

Clair, J. M., Karp, D. A., \& Yoels, W. C. (1993). Experiencing the Life Cycle: A Social Psychology of Aging. Springfield: Charles C Thomas.

Cohen, H. L. (2002). Developing media literacy skills to challenge television's portrayal of older women. Educational Gerontology, 28(7), 599-620.

Degnen, C. (2007). Minding the gap: The construction of old age and oldness amongst peers. Journal of Aging Studies, 21(1), 69-80.

Elzinga, C. H., \& Liefbroer, A. C. (2007). De-standardization of family-life trajectories of young adults: A cross-national comparison using sequence analysis. European Journal of Population/Revue européenne de Démographie, 23(3-4), 225-250.

Entwisle, D. R. (2018). Children, Schools, and Inequality. London: Routledge.

Erol, P. Ö. (2009). Social construction of Old Age among university students in Turkey. Sincronía, (1), 1-16.

Fischer, J. L., Zvonkovic, A., Juergens, C., Engler, R., \& Frederick, H. (2015). Work, family, and well-being at midlife: A person-centered approach. Journal of Family Issues, 36(1), 56-86.

Foss, K. A., \& Southwell, B. G. (2006). Infant feeding and the media: the relationship between Parents' Magazine content and breastfeeding, 1972-2000. International Breastfeeding Journal, 1(1), 1-10.

Government Offices of Sweden, Ministry of Finance. (2017). The Swedish Model. Retrieved from Government Offices of Sweden website: https://www.government.se/information-material/2017/06/the-swedish-model/

Hansen, A., \& Machin, D. (2013). Media and Communication Research Methods. London: Palgrave Macmillan.

Healey, T., \& Ross, K. (2002). Growing old invisibly: older viewers talk television. Media, Culture \& Society, 24(1), 105-120. 
Henderson, L., Kitzinger, J., \& Green, J. (2000). Representing infant feeding: content analysis of British media portrayals of bottle feeding and breast feeding. BMJ, 321(7270), 1196-1198.

Holstein, J. A., \& Gubrium, J. F. (2007). Constructionist perspectives on the life course. Sociology Compass, 1(1), 335-352.

Jamieson, P., \& Romer, D. (2008). The Changing Portrayal of Adolescents in the Media Since 1950. Oxford: Oxford University Press.

Jewitt, C., \& Oyama, R. (2001). Visual meaning: A social semiotic approach. In Van Leeuwen, T., \& Jewitt, C. (eds.), Handbook of Visual Analysis (pp. 134-156). Sage Publishing.

Kessler, E. M., Rakoczy, K., \& Staudinger, U. M. (2004). The portrayal of older people in prime time television series: The match with gerontological evidence. Ageing \& Society, 24(4), 531-552.

Kroon, A. C., Van Selm, M., Ter Hoeven, C. L., \& Vliegenthart, R. (2018). Reliable and unproductive? Stereotypes of older employees in corporate and news media. Ageing \& Society, 38(1), 166-191.

Larsson, A. O. (2013). Bringing it all back home? Social media practices by Swedish municipalities. European Journal of Communication, 28(6), 681-695.

Lee, B., Kim, B. C., \& Han, S. (2006). The portrayal of older people in television advertisements: A cross-cultural content analysis of the United States and South Korea. The International Journal of Aging and Human Development, 63(4), 279-297.

Lee, M. M., Carpenter, B., \& Meyers, L. S. (2007). Representations of older adults in television advertisements. Journal of Aging Studies, 21(1), 23-30.

Lees-Maffei, G., \& Maffei, N.P. (2019). Reading Graphic Design in Cultural Context. London: Bloomsbury Publishing.

Lepianka, D. (2015). How similar, how different? On Dutch media depictions of older and younger people. Ageing \& Society, 35(5), 1095-1113.

Lesko, N. (2012). Act Your Age!: A Cultural Construction of Adolescence. London: Routledge.

Loos, E. (2013). Designing for dynamic diversity: Representing various senior citizens in digital information sources. Observatorio $\left(\mathrm{OBS}^{*}\right), 7(1)$. 21-45.

Loos, E., \& Ekström, M. (2014). Visually representing the generation of older consumers as a diverse audience: Towards a multidimensional market segmentation typology. Participations, 11(2), 258-273.

Loos, E., \& Ivan, L. (2018). Visual ageism in the media. In Ayalon, L., \& Tesch-Römer, C. (eds). Contemporary perspectives on ageism (pp. 163-176). Berlin: Springer.

Loos, E. F., Ivan, L., Fernández-Ardèvol, M., Sourbati, M., Ekström, M., Wilińska, M., Carlo, S., \& Schiau, I. (2017). Ageing well?: A cross-country analysis of the way older people are visually represented on websites of organizations for older people. Journal of Comparative Research in Anthropology and Sociology, 8(2), 63-83. 
Lumme-Sandt, K. (2011). Images of ageing in a 50+ magazine. Journal of Aging Studies, 25(1), 45-51.

Matthews, S. H. (1979). The Social World of Old Women: Management of Selfidentity (78). Sage Publishing.

McMunn, A., Lacey, R., Worts, D., McDonough, P., Stafford, M., Booker, C., ... \& Sacker, A. (2015). De-standardization and gender convergence in work-family life courses in Great Britain: A multi-channel sequence analysis. Advances in Life Course Research, 26, 60-75.

Mergel, I. (2013). A framework for interpreting social media interactions in the public sector. Government Information Quarterly, 30(4), 327-334.

Milner, C., Van Norman, K., \& Milner, J. (2012). The media's portrayal of ageing. Global Population Ageing: Peril or Promise?, 25-28.

Moschis, G. P. (1996). Gerontographics: Life-stage segmentation for marketing strategy development. Santa Barbara: Greenwood Publishing Group.

Moschis, G. P. (2012). Consumer behavior in later life: Current knowledge, issues, and new directions for research. Psychology \& Marketing, 29(2), 57-75.

Narvanen, A. L. (2018). Age, ageing and the life course. In Öberg, B.-M., Närvänen, A.L., Näsman, E. \& Olsson, E. (eds), Changing Worlds and the Ageing Subject: Dimensions in the Study of Ageing and Later Life (pp. 87-102). London: Routledge.

Nelson, E. A., \& Dannefer, D. (1992). Aged heterogeneity: Fact or fiction? The fate of diversity in gerontological research. The Gerontologist, 32(1), 17-23.

OECD. (2018). Digital Government Review of Sweden. Retrieved from OECD website: https://www.oecd.org/gov/digital-government/digital-government-review-of-sweden2018.pdf

Olesen, T. (2018). More than words? A test of the effect of emotionally charged photographs. Nordicom Review, 39(2). 35-48.

Prieler, M., Kohlbacher, F., Hagiwara, S., \& Arima, A. (2015). The representation of older people in television advertisements and social change: the case of Japan. Ageing \& Society, 35(4), 865-887.

Robinson, T., \& Callister, M. (2008). Body image of older adults in magazine advertisements: A content analysis of their body shape and portrayal. Journal of Magazine and New Media Research, 10(1), 1-16.

Robinson, T., \& Popovich, M. (2003). Older adults' perceptions of offensive senior stereotypes in magazine advertisements: Result of a $Q$ method analysis. Educational Gerontology, 29(6), 503-519.

Sedick, S., \& Roos, V. (2011). Older people's portrayal in the print media: implications for intergenerational relations. Journal of Psychology in Africa, 21(4), 549-554.

Skelton, T. (2002). Research on youth transitions: some critical interventions. In: Cieslik, M. \& Pollock, G. (eds). Young People in Risk Society: The Restructuring of Youth Identities and Transitions in Later Modernity (pp. 100-116). Aldershot: Ashgate. 
Tiidenberg, K. (2018). Visibly ageing femininities: women's visual discourses of being over-40 and over-50 on Instagram. Feminist Media Studies, 18(1), 61-76.

Trentham, B., Sokoloff, S., Tsang, A., \& Neysmith, S. (2015). Social media and senior citizen advocacy: an inclusive tool to resist ageism? Politics, Groups, and Identities, 3(3), 558-571.

Vesperi, M. (1985). City of Green Benches: Growing Old in a New Downtown. Ithaca: Cornell University Press.

Vidovićová, L., \& Honelová, M. (2018). A case study of ageism in political debates: are social media a latent source of generational hatred? Slovensky Narodopis, 66(2), 203220.

Volk, A. A., Lukjanczuk, J. L., \& Quinsey, V. L. (2007). Perceptions of child facial cues as a function of child age. Evolutionary Psychology, 5(4), 801-814.

Ylänne, V. (2015). Representations of ageing in the media. In Twigg, J. \& Martin, W. (eds). Routledge Handbook of Cultural Gerontology (pp. 369-376). London: Routledge.

Ylänne, V., Williams, A., \& Wadleigh, P. M. (2010). Ageing well? Older people's health and well-being as portrayed in UK magazine advertisements. International Journal of Ageing and Later Life, 4(2), 33-62.

Zhang, Y. B., Harwood, J., Williams, A., Ylänne-McEwen, V., Wadleigh, P. M., \& Thimm, C. (2006). The portrayal of older adults in advertising: A cross-national review. Journal of Language and Social Psychology, 25(3), 264-282.

Zuckerman, B. S., Frank, D. A., \& Augustyn, M. (1999). Infancy and toddler years. In Levin, M., Carey, W. \& Crocker, A.C. (eds). Developmental-Behavioral Pediatrics (pp. 27-39). Philadelphia: WB Sauders.

Wenqian $\mathrm{Xu}$ is a PhD fellow within the Division Ageing and Social Change (ASC) at Linköping University, Sweden. He holds a Master of Arts in Journalism and Communication from Renmin University of China. Xu has professional experience working in the public information field with UNDP and UNESCAP, and his research interests include ageism, the image of ageing, mediatization and life course.

$\bowtie$ wenqian.xu@liu.se 